\title{
First Report of Marginal Scorch Infecting Indigowoad Root in China
}

\author{
Jinping Wu, Zili Ding, Xiaoyan Liu, Zhenbiao Jiao, Zhengming Qiu, Fengling Guo* \\ Hubei Academy of Agricultural Sciences, Wuhan, China \\ Email: "274184394@qq.com
}

Received 17 May 2016; accepted 19 July 2016; published 22 July 2016

Copyright (C) 2016 by authors and Scientific Research Publishing Inc.

This work is licensed under the Creative Commons Attribution International License (CC BY). http://creativecommons.org/licenses/by/4.0/

(c) (i) Open Access

\begin{abstract}
During 2015, marginal scorch symptoms were detected in the production base of indigowoad rootin Hubei, China. On the basis of morphological features and 185 rDNA sequences, the pathogen was identified as Cladosporium sp. Koch's postulates were fulfilled by pathogenicity tests on potted indigowoad root seedlings. To our knowledge, this report is the first of marginal scorch on indigowoad root caused by Cladosporium sp. We propose the name "marginal scorch" for the new disease.
\end{abstract}

Keywords

Indigowoad Root, Marginal Scorch, Cladosporium sp.

Indigowoad root (Isatis tinctoria) is one of the most well-konwn approved prescription remedies and is frequently used as an anti-leukemia, antipyretic, anti-inflammatory and anti-virus agent [1]. In addition, a compound from indigowoad root granules has been accredited as antiviral agent against influenza virus [2]. Moreover, the fresh leaves are used as a vegetable. As there is more demand for healthy and nutritional life style, the medial role of indigowoad root will get more attention in future. As an important medical vegetable, the planting area of indigowoad roothassignificantly increased. However, the symptom of the marginal scorch for indigowoad root was observed in the Wuhan City andShennongjia Forestry District, Hubei Province, China (Figure 1(a)). First the margin of leaf became yellow, then gradually crispation and brown. The incidence of symptoms was almost $100 \%$, seriously affecting thecommercial quality of the leaves from indigowoad root. Therefore, the pathogens were isolated by tissue segment method on potato dextrose agarmedium [3]. A suspension containing $10^{5}$ conidiophores per ml collected from 7-day-old colonies grown on PDA was sprayed on the foliage of indigowoad root. The control plants were inoculated with sterile water. After inoculation, the plants

*Corresponding author.

How to cite this paper: Wu, J.P., Ding, Z.L., Liu, X.Y., Jiao, Z.B., Qiu, Z.M. and Guo, F.L. (2016) First Report of Marginal Scorch Infecting Indigowoad Root in China. American Journal of Plant Sciences, 7, 1393-1394.

http://dx.doi.org/10.4236/ajps.2016.710132 


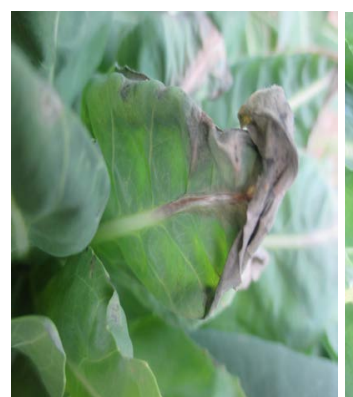

(a)

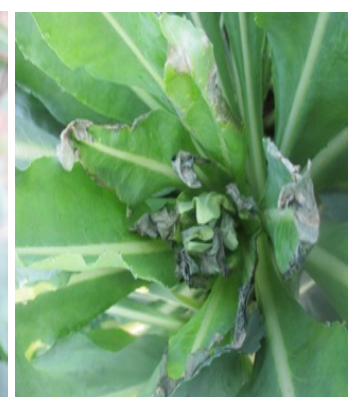

(b)

Figure 1. The symptom of marginal scorchinfecting indigowoad root. (a) Symptoms in field; (b) symptoms after inoculation.

were placed at $25^{\circ} \mathrm{C}$ and $80 \%$ humidity. The first lesions appeared after 7 day (Figure 1(b)). Koch's postulates were fulfilled by consistently reisolating pathogens from inoculated plants, whereas control plants remained healthy. The genomic sequence of $18 \mathrm{~S}$ rDNA was studied. The DNAs of mycelia were extracted with CTAB method [4]. The sequences of primers were designed as follows: 18S-1,5'-GTAGTCATATGCTTGTCTC-3'; 18S-2, 5'-TCCGCAGG TTCACCTACGGA-3'. The PCR reaction conditions were as follows: The settings for the thermal profile included an initial denaturing at $94^{\circ} \mathrm{C}$ for $2 \mathrm{~min}$, followed by 25 cycles of amplification $\left(94^{\circ} \mathrm{C}\right.$ for $30 \mathrm{~s} ; 45^{\circ} \mathrm{C}$ for $30 \mathrm{~s}$; and $72^{\circ} \mathrm{C}$ for $2 \mathrm{~min}$ ) and a finally extension at $72^{\circ} \mathrm{C}$ for $5 \mathrm{~min}$. The PCR products were detected by $1 \%$ agarose gel electrophoresis. A band was detected around $1700 \mathrm{bp}$. The amplification products were ligated, transformed and sequenced. The results were aligned with the sequences in GenBank. The $18 \mathrm{~S}$ rDNA sequence of the representative pathogen isolated from the fresh leaves of the indigowoad root was deposited in GenBank (accession no. KU512834). The basic local alignment search tool (BLAST) was used to indicate functional and evolutionary relationships between sequences, identifying members of gene families. BLAST search of this nucleotide sequence illustrated 99\% identity with 18S rDNA sequences of several Cladosporium sp. isolates available in GenBank. So the species was identified as Cladosporium sp. This is the first reported Cladosporium sp. infection in fresh leaves of the indigowoad rootin China, and we believe that this information will be useful for studying Cladosporium sp. infection in other vegetables. At the same time, our results indicate the need for the revision of indigowoad rootmanagement.

\section{Acknowledgements}

This work was financially supported by the Modern Agricultural Industry Technology System Project Supported by Ministry of Agriculture (nycytx-35-02-06).

\section{References}

[1] Kunikata, T., Tatefuji, T., Tatefuji, T., Aga, H., Iwaki, K., Ikeda, M. and Kurimoto, M. (2001) Indirubin Inhibits Inflammatory Reactions in Delayed-Type Hypersensitivity. European Journal of Pharmacology, 1, 93-100.

[2] Tang, H.Y., Yan, D., Zhang, S.F., Li, H.B., Liu, R.H. and Xiao, X.H. (2010) Agglutinated Activity Bioassay Method for the Determination of Antivirus Prtency of Banlanggen Granula. Acta Pharmacologica Sinica, 45, 479-483.

[3] Rangaswami, G. (1958) An Agar Block Technique for Isolating Soil Micro Organisms with Special Reference to Pythiaceous Fungi. Science and Culture, 24, 85.

[4] Knapp, J.E. and Chandlee, J.M. (1996) RNA/DNA Mini Prep from a Single Sample of Orchid Tissue. Biotechniques, 21, 54-56. 


\section{Submit or recommend next manuscript to SCIRP and we will provide best service for you:}

Accepting pre-submission inquiries through Email, Facebook, LinkedIn, Twitter, etc.

A wide selection of journals (inclusive of 9 subjects, more than 200 journals)

Providing 24-hour high-quality service

User-friendly online submission system

Fair and swift peer-review system

Efficient typesetting and proofreading procedure

Display of the result of downloads and visits, as well as the number of cited articles

Maximum dissemination of your research work

Submit your manuscript at: http://papersubmission.scirp.org/ 